\title{
DNA Ligase I Deficiency
}

National Cancer Institute

\section{Source}

National Cancer Institute. DNA Ligase I Deficiency. NCI Thesaurus. Code C122658.

A very rare genetic syndrome characterized by reduced replicative DNA ligase I. It results

in immunodeficiency and cellular hypersensitivity to DNA-damaging agents. 